\title{
REKONSTRUKSI UNDANG-UNDANG NOMOR 35 TAHUN 2014 TENTANG PERLINDUNGAN ANAK TERHADAP GURU DALAM MENDIDIK SISWA
}

\author{
Dedi Mulyadi ${ }^{1}$
}

\begin{abstract}
ABSTRAK
Perlindungan hukum perlu diberikan kepada anak, karena mereka adalah bagian dari anggota masyarakat yang memiliki kemampuan secara fisik dan mental yang masih terbatas, namun dewasa ini undang-undang perlindungan anak dijadikan sebagai alat oleh orangtua siswa untuk melaporkan guru ke pihak berwajib ketika tidak menyenangi cara guru dalam mendidik siswanya. Adapun tujuan penelitian ini adalah untuk mengetahui dan memahami rekonstruksi perlindungan anak terhadap guru dalam mendidik siswa dan untuk mengetahui dan memahami konsep guru dalam mendidik siswa dalam presfektif Undang-Undang Nomor 35 Tahun 2014 Tentang Perlindungan Anak

Metode penelitian yang digunakan adalah penelitian hukum normatif yang bersifat deskriptif analisis, pengumpulan data dilakukan dengan menggunakan data primer dan data sekunder berupa bahan hukum primer, sekunder dan tertier sebagai data utama. Setelah data sekunder dan primer terkumpul, kemudian diadakan analisis secara kualitatif

Berdasarkan hasil analisis data, disimpulkan bahwa Undang-undang perlindungan anak memberikan dampak terhadap guru dalam mendidik. Undang-undang perlindungan anak membuat guru harus mengubah pola didiknya.Guru berada pada posisi yang dilematis, antara tugas mulia menyalurkan ilmu pengetahuan dan perlakukan orang tua murid. Mereka dituntut untuk mampu menjadikan peserta didik mencapai tujuan pendidikan. Namun saat guru berupaya untuk menegakkan kedisplinan, guru dihadang oleh Undang-Undang Perlindungan Anak. Sehingga muncullah sikap apatis dan ketidakpedulian dari seorang guru terhadap tingkah laku murid karena mereka takut berhadapan dengan hukum walaupun undang-undang telah memberikan perlindungan kepadanya. Oleh sebab itu, pasal-pasal perlindungan anak yang membatasi ruang gerak guru dalam melaksanakan proses pendidikan di sekolah harus di rekronstruksi kembali.
\end{abstract}

\section{Kata Kunci: Perlindungan Anak, Guru, Mendidik Siswa}

\footnotetext{
${ }^{1}$ Guru SMPN 2 Panyingkiran Majalengka. Email : Dedimulyadi240370@gmail.com
} 
PRESUMPTION of LAW

Fakultas Hukum Universitas Majalengka

Volume 3 Nomor 2 Oktober 2021

\section{A. Latar Belakang}

Elemen penting dalam dunia pendidikan adalah guru dan siswa. Guru disamping memberikan pengetahuan kepada siswanya, juga memiliki peran pembentukan karakter siswanya, sehingga peran mengayomi adalah hal yang utama. Profesi guru memiliki tanggungjawab besar, karena guru memiliki peran pembentukan karakter siswanya, sehingga negara sangat berharap kepada guru dalam mencetak generasi yang berakhlak dan berintegritas Profesi guru memiliki fungsi yang strategis, sehingga perlu dihargai sebagai profesi yang bermartabat ${ }^{2}$

Guru adalah seorang pendidik yang memiliki pekerjaan mulia, guru merupakan kunci utama kemajuan suatu negara dimana membina dan menciptakan generasi muda yang berkualitas dan bermoral yang tinggi untuk bangsa dan negara. Guru merupakan profesi yang sangat mulia bagi masyarakat karena dianggap sebagai sosok yang akan membantu mereka dalam hal menanamkan nilai-nilai kebaikan kepada siswa. Masyarakat memberikan kepercayaan penuh kepada guru dalam hal mendidik siswanya di sekolah walaupun dengan cara kekerasan sekalipun. Namun, kepercayaan masyarakat terhadap cara guru dalam mendidik siswanya mulai memudar seiring perkembangan zaman dan disahkannya undang-undang perlindungan anak

Realitasnya, proses pendidikan tidak dapat berjalan sebagaimana mestinya, karena terjadinya ketidaktertiban dari peserta didik, sehingga guru perlu melakukan tindakan pendisiplinan guna membenahi perilaku atau karakternya, namun kerapkali yang terjadi adalah peserta didik merasa mendapat perlakuan kekerasan, sehingga persoalan muncul dimana letak perbedaan antara tindakan pendisiplinan dan tindakan kekerasan, dimana pendisiplinan ini memang perlu dilakukan, Kondisi ini memunculkan tuntutan pentingnya pemenuhan dan perlindungan anak. ${ }^{3}$

Marlina menyatakan bahwa "Masalah perlindungan hukum bagi anak merupakan salah satu cara melindungi tunas bangsa di masa depan, perlindungan hukum terhadap anak menyangkut semua aturan yang berlaku. Perlindungan ini perlu karena anak merupakan bagian dari masyarakat yang mempunyai keterbatasan secara fisik dan mental. Oleh karena itu memerlukan perlindungan dan perawatan khusus"

Tujuan utama dari Undang-Undang Perlindungan anak adalah untuk menjamin dan melindungi Anak dan hak-haknya agar dapat hidup, tumbuh, berkembang, dan berpartisipasi secara optimal sesuai dengan harkat dan martabat kemanusiaan, serta mendapat perlindungan dari kekerasan dan diskriminasi. Secara teoritik, anak-anak Indonesia dijamin dalam menjalani hidupnya.

${ }^{2}$ Yenny AS, Anita Yuliastini, Rini Setiawati, Membangun Kesadaran Hukum Tentang Perlindungan Anak Bagi Guru, Jces (Journal of Character Education Society), Vol. 3, No. 3, Oktober 2020, hlm 544, file://C:/Users/MINI\%20PC/Downloads/2580-10663-2-PB.pdf, diakses pada tanggal 10 Juli 2021 Pukul 23.15 WIB

${ }^{3}$ Ibid,

${ }^{4}$ Marlina, Peradilan Pidana Anak di Indonesia, Refika Aditama Bandung, 2012 hlm. 42 
PRESUMPTION of LAW

Fakultas Hukum Universitas Majalengka

Volume 3 Nomor 2 Oktober 2021

Dalam Undang-Undang Perlindungan Anak pada Pasal 1 UndangUndang Republik Indonesia Nomor 35 Tahun 2014 Tentang Perlindungan Anak dijelaskan bahwa yang dimaksud dengan perlindungan anak adalah segala kegiatan untuk menjamin dan melindungi anak dan hak-haknya agar dapat hidup, tumbuh, berkembang, dan berpartisipasi secara optimal sesuai dengan harkat dan martabat kemanusiaan, serta mendapat perlindungan dari kekerasan dan diskriminasi. Secara spesifik perlindungan anak di sekolah dijelaskan pada Pasal 54 Undang-Undang Republik Indonesia Nomor 35 Tahun 2014 Tentang Perlindungan Anak bahwa setiap anak berhak mendapatkan perlindungan di satuan pendidikan dari kejahatan seksual dan kekerasan yang dilakukan oleh pendidik, tenaga kependidikan, sesama peserta didik, dan/atau pihak lain.

Secara hukum, undang-undang ini bermaksud menjamin hak anak-anak Indonesia dalam mendapatkan layanan pendidikan dan mejalani kehidupanya. Hal tersebut dapat dipahami karena anak-anak termasuk bagian dari anggota masyarakat yang sangat rawan mengalami tindakan kekerasan dan pelecehan ${ }^{5}$.

Undang-undang perlindungan anak digunakan agar dapat menjamin perlindungan hukum bagi anak ketika beraktifitas di masyarakat dan mengikuti proses pendidikan di sekolah. Perlindungan hukum perlu diberikan kepada anak karena mereka adalah bagian dari anggota masyarakat yang memiliki kemampuan secara fisik dan mental yang masih terbatas. ${ }^{6}$ Oleh karena itu, dapat dipahami bahwa anak memerlukan perlindungan secara khusus karena mereka merupakan generasi penerus perjuangan bangsa yang harus dilindugi, namun dewasa ini Undang-Undang Perlindungan Anak kemudian dijadikan sebagai alat oleh orangtua siswa untuk melaporkan guru ke pihak berwajib ketika tidak menyenangi cara guru dalam mendidik siswanya. Padahal dalam melaksanakan tugasnya, guru telah diberikan kebebasan untuk menilai dan sebagai penentu kelulusan siswa, memberikan penghargaan serta dapat memberikan sanksi yang mendidik kepada siswa sesuai dengan kode etik guru dan peraturan perundang-undangan yang berlaku. ${ }^{7}$

Berdasarkan dari latar belakang tersebut, maka penulis tertarik untuk melakukan penelitian lebih lanjut yang akan dituangkan dalam bentuk penelitian dengan judul "Rekonstruksi Undang-Undang Nomor 35 Tahun 2014 Tentang Perlindungan Anak Terhadap Guru Dalam Mendidik Siswa"

5 Ahmad Munawir, paradigma guru dan orangtua terhadap penerapan UndangUndang Perlindungan Anak Di Sekolah, Al-Amwal: Journal of Islamic Economic Law

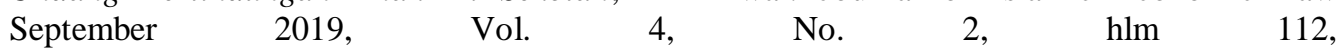
https://ejournal.iainpalopo.ac.id/index.php/alamwal/index diakses pada tanggal 10 Juli 2021 Pukul 23.15 WIB

${ }^{6}$ Marlina, Peradilan Pidana Anak di Indonesia...Loc.Cit

${ }^{7}$ E Mulyasa, Menjadi Guru Profesional, Remaja Rosdakarya, Bandung, 2006, hlm 33 
PRESUMPTION of LAW

Fakultas Hukum Universitas Majalengka

Volume 3 Nomor 2 Oktober 2021

\section{B. Rumusan Masalah}

Berdasarkan uraian di atas, pokok permasalahan yang akan dibahas dalam jurnal ini adalah sebagai berikut:

1. Bagaimanakah Rekonstruksi Perlindungan Anak Terhadap Guru Dalam Mendidik Siswa?

2. Bagaimanakah Konsep Guru Dalam Mendidik Siswa dalam Presfektif Undang-Undang Nomor 35 Tahun 2014 Tentang Perlindungan Anak?

\section{Tujuan Penelitian}

Sesuai dengan rumusan masalah yang dirumuskan, maka penelitian ini bertujuan untuk:

1. Untuk mengetahui dan memahami Rekonstruksi Perlindungan Anak Terhadap Guru Dalam Mendidik Siswa

2. Untuk mengetahui dan memahami Konsep Guru Dalam Mendidik Siswa dalam Presfektif Undang-Undang Nomor 35 Tahun 2014 Tentang Perlindungan Anak

\section{Metode penelitian;}

Jenis penelitian yang digunakan dalam penelitian ini adalah penelitian hukum normatif yang berfokus pada norma hukum positif yang mengatur tentang perlindungan hukum terhadap guru di Indonesia. Penelitian hukum normatif disebut juga penelitian hukum doktrinal. ${ }^{8}$ Dimana hukum dikonsepsikan sebagai apa yang tertulis dalam peraturan perundang-undangan (law in books) atau hukum yang dikonsepsikan sebagai kaidah atau norma yang merupakan patokan berprilaku masyarakat terhadap apa yang dianggap pantas.

Berdasarkan tipe penelitiannya yang normatif, maka pendekatan yang utama digunakan adalah pendekatan perundang-undangan (statute approach), karena yang akan diteliti adalah berbagai aturan hukum yang menjadi fokus sekaligus tema sentral penelitian. ${ }^{9}$

Seperti yang telah dikemukakan di atas mengenai tipe penelitian dalam penyusunan jurnal ini adalah yuridis normatif, maka bahan hukum yang digunakan dalam hal ini terdiri atas bahan hukum primer, bahan hukum sekunder, serta bahan-bahan hukum tersier. Bahan hukum primer yaitu bahan hukum yang terdiri atas peraturan perundang-undangan secara hierarki dan putusan pengadilan. Bahan hukum sekunder yang digunakan disini adalah bahan-bahan yang memberikan penjelasan mengenai bahan hukum primer, yaitu buku teks, jurnal hukum, pendapat para pakar, yang kesemuanya itu berhubungan erat dengan pokok permasalahan. Bahan hukum tersier, yaitu bahan hukum yang memberikan petunjuk maupun penjelasan terhadap bahan

\footnotetext{
${ }^{8}$ Jonaedi Efendi, Johnny Ibrahim, Metode Penelitian Hukum Normatif dan Empiris, Prenadamedia Group, Depok, 2018, hlm. 124.

9 Johnny Ibrahim, Teori dan Metodologi Penelitian Hukum Normatif, Bayumedia Publishing, Cet. IV, Malang, 2008, hlm. 302.
} 
PRESUMPTION of LAW

Fakultas Hukum Universitas Majalengka

Volume 3 Nomor 2 Oktober 2021

hukum primer dan sekunder yang berkaitan dengan penelitian ini yaitu berupa Kamus Besar Bahasa Indonesia dan Kamus Hukum.

Guna lebih mempermudah pembahasan, maka informasi yang didapat dan diperoleh selanjutnya dihimpun melalui proses yang bertahap. Berawal dari sumber-sumber yang tertulis yang berasal dari peraturan perundangundangan dan tulisan-tulisan lain yang berhubungan dengan inti permasalahan. Selanjutnya bahan-bahan hukum yang sudah berhasil dikumpulkan diolah sesuai dengan keperluan untuk dijadikan bahan pembahasan dengan jalan menghimpun dan mengklasifikasikannya dalam masing-masing bab dan sub bab yang telah disusun berurutan menurut pokok permasalahan untuk kemudian dianalisis.

Bahan-bahan hukum yang sudah dikumpulkan tersebut dianalisis dengan berpedoman pada metode kualitatif, yaitu suatu cara penelitian yang menghasilkan informasi deskriptif analitis, dan terkumpul untuk kemudian menguraikan fakta yang telah ada dalam jurnal ini kemudian ditarik suatu kesimpulan dan saran dengan memanfaatkan cara berpikir deduktif yaitu menarik kesimpulan yang berangkat dari hal-hal yang bersifat umum menuju hal-hal yang bersifat khusus. ${ }^{10}$

\section{E. Pembahasan}

\section{Rekonstruksi Perlindungan Anak Terhadap Guru Dalam Mendidik Siswa}

Secara spesifik disebutkan dalam Pasal 54 Undang-Undang No. 35 Tahun 2014 tentang Perubahan Atas Undang-Undang No. 23 Tahun 2002 tentang Perlindungan Anak, menyatakan bahwa anak di dalam dan di lingkungan satuan pendidikan wajib mendapatkan perlindungan dari tindak Kekerasan fisik, psikis, kejahatan seksual, dan kejahatan lainnya yang dilakukan oleh pendidik, tenaga kependidikan, sesama peserta didik, dan/atau pihak lain.

Undang-undang perlindungan anak dimaksudkan agar anak dapat dilindungi haknya untuk aman dari perilaku kekerasan dan diskriminasi serta terjamin haknya untuk tumbuh dan berkembang serta turut berpartisipasi

dalam kehidupan berbangsa seusai dengan kemampuannya ${ }^{11}$ Secara hukum, undang-undang ini bermaksud menjamin hak anak-anak indonesia dalam mendapatkan layanan pendidikan dan mejalani kehidupanya. Hal tersebut dapat dipahami karena anak-anak termasuk bagian dari anggota masyarakat yang sangat rawan mengalami tindakan kekeresan dan pelecehan.

Undang-Undang Perlindungan anak mempunyai tujuan untuk menjamin dan melindungi Anak dan hak-haknya agar dapat hidup, tumbuh,

10 Ateng Sudibyo dan Eki Kiyamudin, perlindungan hukum terhadap guru dalam melaksanakan tugas keprofesionalannya dikaitkan dengan punishment dalam mendisiplinkan siswa, Presumption Of Law, Fakultas Hukum Universitas Majalengka, Volume 1 Nomor 2 Tahun 2019, hlm 54, https://ejournal.unma.ac.id/index.php/jpl/article/view/89, hlm 54, diakses pada tanggal 03/09/2021. Pukul 08.52 WIB

${ }^{11}$ Ahmad Munawir, paradigma guru dan orangtua terhadap ....Loc.Cit 
PRESUMPTION of LAW

Fakultas Hukum Universitas Majalengka

Volume 3 Nomor 2 Oktober 2021

berkembang, dan berpartisipasi secara optimal sesuai dengan harkat dan martabat kemanusiaan, serta mendapat perlindungan dari kekerasan dan diskriminasi. Secara teoritik, anak-anak Indonesia dijamin dalam mejalani hidupnya.

Undang-undang perlindungan Anak juga berperan positif dalam memberikan jaminan hukum kepada anak atau siswa dalam mengikuti pembelajaran di sekolah. Seorang siswa akan mendapatkan kepastian untuk menerima pembelajaran dengan baik dari guru yang mengajar di sekolahnya. Undang-Undang ini juga menjamin seorang siswa dalam mengembangkan pengetahuan, meningkatkan kreativitas, dan ekspresi belajar dalam menguasai pembelajaran yang diberikan oleh gurunya. Namun tanpa disadari, Undang-Undang Perlindungan Anak seolah membawa dampak negatif kedalam dunia pendidikan dan sepertinya memberikan kesan imunitas bagi

siswa atau keluarga siswa yang merasa menjadi korban. ${ }^{12}$ Dalam menempuh pendidikan tidak semua siswa yang berprilaku baik, ada juga siswa yang nakal dan tugas seorang guru diantaranya adalah mendidik, mengajar, membimbing, mengarahkan, melatih, menilai, dan mengevaluasi peserta didik pada pendidikan anak usia dini jalur pendidikan formal, pendidikan dasar dan pendidikan menengah.

Dalam mendidik, mengajar, membimbing hingga mengevaluasi siswa, guru diberikan kebebasan akademik untuk melakukan metode-metode yang ada. Selain itu, guru juga tidak hanya berwenang memberikan penghargaan terhadap siswanya, tetapi juga memberikan punishment kepada siswanya tersebut.

Pasal 39 ayat (1) dan ayat (2) Peraturan Pemerintah Nomor 74 Tahun 2008 tentang Guru menyatakan :

(1). Guru memiliki kebebasan memberikan sanksi kepada peserta didiknya yang melanggar norma agama, norma kesusilaan, norma kesopanan, peraturan tertulis maupun tidak tertulis yang ditetapkan guru, peraturan tingkat satuan pendidikan, dan peraturan perundang-undangan dalam proses pembelajaran yang berada di bawah kewenangannya,

(2). Sanksi tersebut dapat berupa teguran dan/atau peringatan, baik lisan maupun tulisan, serta hukuman yang bersifat mendidik sesuai dengan kaedah pendidikan, kode etik guru, dan peraturan perundang-undangan.

Begitu pula dalam hal mendidik, guru diberi perlindungan oleh hukum dalam menjalankan tugasnya sebagai pendidik, perlindungan tersebut termuat dalam Pasal 40 sampai Pasas 42 Paraturan Pemerintah Nomor 74 Tahun 2008 tentang Guru

Pasal 40

(1). Guru berhak mendapat perlindungan dalam melaksanakan tugas dalam bentuk rasa aman dan jaminan keselamatan dari Pemerintah,

12 Agus Affandi, Dampak Pemberlakuan Undang-Undang Perlindungan Anak Terhadap Guru Dalam Mendidik Siswa, Jurnal Hukum Samudra Keadilan Volume 11, Nomor 2, Juli-Desember 2016, hlm 198 https://jurnal.unsam.ac.id/index.php/jhsk/article/view/37/18 diakses pada tanggal 10 Juli 2021 Pukul 23.15 WIB 
PRESUMPTION of LAW

Fakultas Hukum Universitas Majalengka

Volume 3 Nomor 2 Oktober 2021

Pemerintah Daerah, satuan pendidikan, Organisasi Profesi Guru, dan/atau Masyarakat sesuai dengan kewenangan masing-masing.

(2). Rasa aman dan jaminan keselamatan dalam melaksanakan tugas sebagaimana dimaksud pada ayat (1) diperoleh Guru melalui perlindungan: a. hukum; b. profesi; dan c. keselamatan dan kesehatan kerja

(3). Masyarakat, Organisasi Profesi Guru, Pemerintah atau Pemerintah Daerah dapat saling membantu dalam memberikan perlindungan sebagaimana dimaksud pada ayat (1).

Pasal 41

(1). Guru berhak mendapatkan perlindungan hukum dari tindak kekerasan, ancaman, perlakuan diskriminatif, intimidasi, atau perlakuan tidak adil dari pihak peserta didik, orang tua peserta didik, Masyarakat, birokrasi, atau pihak lain.

(2). Guru berhak mendapatkan perlindungan profesi terhadap pemutusan hubungan kerja yang tidak sesuai dengan ketentuan peraturan perundang-undangan, pemberian imbalan yang tidak wajar, pembatasan dalam menyampaikan pandangan, pelecehan terhadap profesi, dan pembatasan atau pelarangan lain yang dapat menghambat Guru dalam melaksanakan tugas.

(3). Guru berhak mendapatkan perlindungan keselamatan dan kesehatan kerja dari satuan pendidikan dan penyelenggara satuan pendidikan terhadap resiko gangguan keamanan kerja, kecelakaan kerja, kebakaran pada waktu kerja, bencana alam, kesehatan lingkungan kerja dan/atau resiko lain

Pasal 42

Guru memperoleh perlindungan dalam melaksanakan hak atas kekayaan intelektual sesuai dengan ketentuan peraturan perundang-undangan.

Kenyataannya sekarang apa yang terjadi terhadap guru. Guru dipidana oleh orang tua murid karena memberikan hukuman kepada anakanya. Adapun yang menjadi dasar orang tua murid memidanakan Guru UndangUndang perlindungan Anak Seperti yang terjadi di Majalengka, Jawa Barat seorang guru hanya gara-gara mencukur rambut salah satu siswanya, harus duduk dikursi pesakitan. Dalam persidangan, guru tersebut terbukti bersalah dan divonis tiga bulan penjara dengan masa percobaan enam bulan. Meski dikenakan pasal berlapis dan dijatuhi hukuman percobaan, tapi oleh Mahkamah Agung hukuman itu dianulir dan menjatuhkan vonis bebas kepada guru tersebut. Berdasarkan Yurisprudensi Mahkamah Agung, guru tidak bisa dipidanakan saat menjalankan profesinya dan melakukan tindakan pendisiplinan terhadap siswa. Menurut mantan Wakil Ketua MPR RI Hidayat Nur Wahid bahwa" tindakan guru yang menegur atau menghukum muridnya dalam rangka penerapan disiplin selama masih dalam koridor pendidikan tidak bisa dipidanakan, kalau sekedar mencubit atau dihukum hanya karena ingin menegakkan disiplin lantas diadukan ke penegak hukum, bagaimana nasib pendidikan kita? Peran dan tugas guru bukan hanya sebagai pengajar yang menyampaikan ilmu pengetahuan, 
PRESUMPTION of LAW

Fakultas Hukum Universitas Majalengka

Volume 3 Nomor 2 Oktober 2021

keterampilan, bimbingan, petunjuk, merancang dan melaksanakan pembelajaran serta menilai saja, tetapi guru juga sebagai pendidik adalah untuk mengembangkan kepribadian dan membina budi pekerti. ${ }^{13}$

Adanya perbedaan paham dan persepsi yang berbeda antara guru dan orangtua dalam mendidik anak, menjadi penyebab banyaknya kesalahpahaman terhadap cara dan pola didik guru. Para orangtua yang keberatan dengan cara Guru mendisiplinkan anak dengan menggunakan symbol-symbol kekerasan seperti; menjewer, mencubil, memukul, mencukur dan bentuk- bentuk pendisiplinan lainnya sehingga guru dikriminalisasikan

Pasal 80 ayat (1) Undang-Undang Nomor 35 tahun 2014 tentang Perubahan Atas Undang-Undang Nomor 23 Tahun 2002 Tentang Perlindungan Anak, merupakan pasal yang digunakan oleh orang tua murid melaporkan guru yang memberikan hukuman kepada muridnya. Seperti yang dialami oleh Nurmayani Guru bidang studi biologi SMP Negeri 1 Bantaeng mencubit siswanya yang kebetulan anak polisi kemudian berakhir di sel penjara. Kasus serupa juga dialami oleh Sambudi guru SMP swasta di Sidoarjo, karena mencubit siswanya karena asyik nongkrong di tepi sungai saat ada kegiatan salat berjamaah di mushala sekolah dan orangtua siswa yang berprofesi sebagai anggota TNI Angkatan Darat melaporkannya dengan tuduhan penganiayaan. Kasus seorang guru yang bernama Muhammad Samhudi. Muhammad Samhudi dituntut oleh Jaksa Penuntut Umum enam bulan penjara dengan masa percobaan satu tahun karena dinilai bersalah dan melanggar Pasal 80 ayat (1) Undang-Undang Perlindungan Anak $^{14}$

Undang-undang perlindungan anak memberikan dampak terhadap guru dalam mendidik. Guru berada pada posisi yang dilematis, antara tugas mulia menyalurkan ilmu pengetahuan dan perlakukan orang tua murid. Mereka dituntut untuk mampu menjadikan peserta didik mencapai tujuan pendidikan. Namun saat guru berupaya untuk menegakkan kedisplinan, guru dihadang oleh Undang-Undang Perlindungan Anak. Sehingga muncullah sikap apatis dan ketidakpedulian dari seorang guru terhadap tingkah laku murid karena mereka takut berhadapan dengan hukum walaupun undang-undang telah memberikan perlindungan kepadanya.

Undang-undang perlindungan anak bukanlah benteng atau senjata untuk menjatuhkan atau apalagi mengancam guru dalam mendidik. Terbentuknya undang- undang perlindungan anak untuk dipelajari oleh setiap warga negara bahwa setiap anak dihargai dan dilindungi. Begitu juga dengan tugas mendidik bukanlah sepenuhnya tugas guru. Orang tua adalah pendidik utama bagi anak-anak mereka. Bagaimana cara dan disiplin orang tua mendidik anak-anak mereka dapat menjadi acuan para guru dalam

${ }^{13}$ Jumriani Nawawi, Perlindungan Hukum Terhadap Profesi Guru Dari Kriminalisasi Di Indonesia, Jurnal Al-Adalah: Jurnal Hukum dan Politik Islam Vol. 4, No. 2, Juli 2019, hlm 161, https://media.neliti.com/media/publications/326816-perlindungan-hukum-terhadap-gurudari-kr-65ae2e71.pdf diakses pada tanggal 10 Juli 2021 Pukul 23.15 WIB

${ }^{14}$ Agus Affandi, Dampak Pemberlakuan Undang-Undang...Op.Cit, hlm 202 
PRESUMPTION of LAW

Fakultas Hukum Universitas Majalengka

Volume 3 Nomor 2 Oktober 2021

membentuk karakter setiap peserta didik. Kurang kepercayaan dari masyarakat kepada guru menjadi salah satu kendala yang dihadapi guru. Keyakinan dan kepercayaan ini seolah memudar dari masyarakat yang menyebabkan guru merasa tertekan dalam setiap tindakan yang diambil untuk menyiplinkan siswanya.

Guru akan merasa trauma dan bahkan malas mendidik. Guru terperangkap oleh undang-undang perlindungan anak apabila mereka mencoba mensiplinkan murid. Sikap dari ketakutan guru dalam mendidiplinkan siswa akan berdampak lebih besar. Pendidikan Indonesia akan terhenti tanpa ada pergerakan apabila sikap guru malas mensiplinkan siswanya. ${ }^{15}$

Dengan sikap guru yang demikian maka akan berdampak pada perkembangan dan kemajuan bangsa. Perkembangan dan kemajuan bangsa terletak pada pendidikan, fungsi pendidikan adalah untuk mengembangkan kemampuan dan membentuk watak serta peradaban bangsa yang bermartabat dalam rangka mencerdaskan kehidupan bangsa, bertujuan untuk berkembangnya potensi peserta didik agar menjadi manusia yang beriman dan bertakwa kepada Tuhan Yang Maha Esa, berakhlak mulia, sehat, berilmu, cakap, kreatif, mandiri, dan menjadi warga negara yang demokratis serta bertanggung jawab. Dengan ketakutan guru dalam memberikan hukuman kepada muridnya maka pendidikan tersebut tidak akan berhasil. Keberhasilan pendidikan dapat dilihat dari perbaikan sikap dan perilaku peserta didik dalam hal ini murid, karena tujuan utama dari pendidikan ialah memperbaiki kualitas manusia, maka pendidikan yang berhasil ialah pendidikan yang menghasilkan manusia yang berpengetahuan dan berakhlak mulia. Oleh karena itu, jika Pasal 80 ayat (1) Undang-Undang Nomor 35 tahun 2014 tentang Perubahan Atas Undang-Undang Nomor 23 Tahun 2002 Tentang Perlindungan Anak, merupakan pasal yang digunakan oleh orang tua murid melaporkan guru yang memberikan hukuman kepada muridnya harus direkonstruksi karena nilai kebijakan hukum dalam perlindungan hukum terhadap guru tersebut tidak memberikan kepastian hukum dan rasa keadilan yaitu keadilan restoratif .

Menurut Pakar hukum pidana Universitas Islam Indonesia (UII), Muzakir mengatakan bahwa:

UU Perlindungan Anak yang kerap dijadikan senjata tersebut memang agak kaku.Seharusnya dilihat dulu maksud dan tujuan guru memukul itu apa. Muzakir menjelaskan jika memukul tersebut bertujuan penganiyaan maka bisa digolongkan ke tindak pidana. Namun jika bertujuan untuk mendidik, seharusnya bisa diselesaikan melalui jalur kekeluargaan dan tidak perlu ke pengadilan, ada dewan guru di sekolah yang bisa menyelesaikan. Muzakir menjelaskan maraknya guru dipidana, seharusnya ditelaah lebih dahulu kasus per kasus. Kalau undang-undang ditafsirkan saklek itu bisa jadi bumerang bagi guru. Orangtua, seharusnya juga bisa mengontrol emosi dan lebih 
PRESUMPTION of LAW

Fakultas Hukum Universitas Majalengka

Volume 3 Nomor 2 Oktober 2021

bijaksana ketika anaknya mengalami kekerasan di sekolah. Kekhawatiran yang muncul jika aduan anak ditelan mentah-mentah, adalah anak-anak tersebut bisa di atas angin. Imbasnya tentu tidak baik bagi guru dan murid. ${ }^{16}$

Undang-undang perlindungan anak bukanlah benteng atau senjata untuk menjatuhkan atau apalagi mengancam guru dalam mendidik. Terbentuknya undang-undang perlindungan anak untuk dipelajari oleh setiap warga negara bahwa setiap anak dihargai dan dilindungi. Begitu juga dengan tugas mendidik bukanlah sepenuhnya tugas guru. Orang tua adalah pendidik utama bagi anak-anak mereka. Bagaimana cara dan disiplin orang tua mendidik anak-anak mereka dapat menjadi acuan para guru dalam membentuk karakter setiap peserta didik. Kurang kepercayaan dari masyarakat kepada guru menjadi salah satu kendala yang dihadapi guru. Keyakinan dan kepercayaan ini seolah memudar dari masyarakat yang menyebabkan guru merasa tertekan dalam setiap tindakan yang diambil untuk menyiplinkan siswanya.

Menanggapi hal ini, juga mesti melihat Undang-Undang Guru dan Dosen yang memberikan kewenangan mandat dan perlindungan kepada para pendidik. Berdasarkan Pasal 1 Angka 1 Undang-Undang Nomor 14 Tahun 2005 tentang Guru dan Dosen menyatakan, "Guru adalah pendidik profesional dengan tugas utama mendidik, mengajar, membimbing melatih, menilai, dan mengevaluasi peserta didik pada pendidikan dasar, dan pendidikan menengah". Dalam menjalankan tugas sebagai pendidik, guru mempunyai kewenangan dalam memberikan sanksi jika peserta didik dianggap melakukan kesalahan. Sanksi dapat berupa teguran atau peringatan, baik lisan maupun tertulis, serta hukuman yang bersifat memberikan efek jera kepada peserta didik.

Persepsi yang berbeda dari orang tua dan pihak sekolah terutama guru sebagai pelaku pendidik. Hukuman yang bersifat memberikan efek jera seperti mencubit sudah dianggap sebagai pelanggaran HAM berdasarkan undang-undang perlindungan anak menurut persepsi orang tua. Sedangkan pihak guru masih menganggap sanksi tersebut masuk dalam kategori mendidik. Hal ini memang jauh berbeda dengan pola pendidikan pada jaman dulu, jika anak mendapatkan hukuman dari guru kemudian melaporkan kepada orang tua, bisa jadi orang tua justru akan memarahi anak tersebut bahkan menambahkan hukuman di rumah.

Merupakan hal yang wajar jika orang tua melindungi anaknya, akan tetapi orang tua juga harus berpikir ulang jika anak tersebut telah melakukan pelanggaran yang cukup berat. Alangkah bijaknya jika orang tua juga mempunyai persepsi yang sama dengan pihak sekolah. Pelaporan orang tua terhadap guru tentu akan menghentikan gerak guru dalam mendidik

${ }^{16}$ Brilio, Benarkah guru pukul murid itu melanggar undang-undang? Ini jawabannya, https://www.brilio.net/serius/benarkah-guru-pukul-murid-itu-melanggar-undang-undang-inijawabannya-160812f.html diakses pada tanggal 10 Juli 2021 Pukul 23.15 WIB 
PRESUMPTION of LAW

Fakultas Hukum Universitas Majalengka

Volume 3 Nomor 2 Oktober 2021

siswanya, dengan sedikit cubitan, gertakan dan lainnya, guru dianggap telah melakukan penganiayaan terhadap anak

Selama hukuman tersebut tidak merupakan tindak kekerasan berlebihan dan mempunyai alasan yang jelas dalam mendidik, harusnya ada sedikit kesadaran dari orang tua dalam menyikapi hal tersebut. Terkecuali jika anak mendapatkan penganiayaan tanpa sebab atau pemberian sanksi yang membuat luka berat mungkin. Hal yang semacam ini bisa dikategorikan sebagai penganiayaan terhadap anak. ${ }^{17}$

\section{Konsep Guru Dalam Mendidik Siswa dalam Presfektif Undang-Undang Nomor 35 Tahun 2014 Tentang Perlindungan Anak}

Pasal 54 UU No.35 Tahun 2014 tentang perlindungan anak sudah sangat jelas dikatakan bahwa anak di lingkungan sekolah wajib dilindungi dari tindakan kekerasan yang dilakukan oleh guru, pengelola sekolah atau teman-temanya di dalam sekolah yang bersangkutan, atau lembaga pendidikan lainya $^{18}$

Adapun sanksi hukum atas kekearasan di sekolah adalah tindakan pelangaran hukum yang bisa di pidana dengan Kitab Undang Undang Hukum Pidana (KUHP). Ketentuan dalam KUHP tentang penganiayaan, fitnah, penhinaan, perbuatan asusila, perkosaan, pencemaran nama baik, perbuatan tidak menyenangkan, bisa digunakan untuk mendakwa para pelaku dan membawanya ke penjara. Selain itu UU No.35 Tahun 2014 tentang Perlindungan Anak memuat sanksi pidana bagi para pelaku kekearasan terhadap anak. Ketentuan pidana ini termuat dalam Bab XII dari Pasal 77 hingga Pasal 90 UU No.35 Tahun 2014 tentang Perlindungan Anak. Kekearasan di sekolah juga bisa di gugat secara perdata. Gugatan perdata bisa diajukan ke pengadilan negri terhadap pelaku kekerasan di sekolah atau pihak sekolah sebagai lembaga berupa gugatan ganti rugi material dan imaterial dalam bentuk uang atau natura. Gugatan ini mengacu pada kitab UndangUndang Hukum Perdata dengan pasal-pasal berikut:

a. Pasal 1365 Tiap perbuatan melanggar hukum yang membawa kerugian kepada seorang lain, mewajibkan orang yang karena salahnya menerbitkan kerugian itu, mengganti kerugian tersebut

b. Pasal 1366 Seiap orang bertanggung jawab tidak saja untuk kerugian yang disebabkan karena perbuatanya, tetapi juga untuk kerugian yang disebabkan karena kelalaian, atau kurang hatihatinya.

c. Pasal 1367 Guru sekolah bertanggung jawab tentang kerugian yang diterbitkan oleh murid selama waktu murid itu berada dibawah pengawasan mereka, kecuali, jika mereka dapat membuktikan bahwa

${ }^{17}$ Jumriani Nawawi, Perlindungan Hukum Terhadap Profesi Guru Dari Kriminalisasi Di Indonesia.... Op.Cit...hlm 169

18 Michael Pranoto, Implementasi Pasal 54 Undang-Undang No. 35 Tahun 2014 Tentang Perlindungan Anak Di Lingkungan Sekolah, Lex Crimen Vol. VI/No. 8/Okt/2017, https://ejournal.unsrat.ac.id/index.php/lexcrimen/article/view/17933/17460, diakses pada tanggal 10 Juli 2021 Pukul 23.15 WIB 
PRESUMPTION of LAW Fakultas Hukum Universitas Majalengka

mereka tidak dapat mencegah perbuatan yang mesti mereka seharusnya bertanggung jawab. ${ }^{19}$

Adapun dalam Yurisprudensi Mahkamah Agung yang menyatakan bahwa Guru tidak bisa dipidana saat menjalankan profesinya dan melakukan tindakan pendisiplinan terhadap siswa. Hal itu diputuskan saat mengadili guru SD dari Majalengka Jawa Barat yang bernama Aop Saopudin.

Guru secara normatif, memang telah mendapatkan perlindungan, sebagaimana ketentuan Pasal 39 Undang-Undang Nomor 14 Tahun 2005 ayat (1): "Pemerintah, pemerintah daerah, masyarakat, organisasi profesi, dan/atau satuan pendidikan wajib memberikan perlindungan terhadap guru dalam pelaksanaan tugas". Rumusan undang-undang tersebut telah memberikan dan mewajibkan adanya perlindungan kepada guru dalam tugasnya. Perlindungan guru dalam ayat (2) pasal ini meliputi: perlindungan hukum, perlindungan profesi, dan perlindungan keselamatan dan kesehatan kerja. Disamping itu guru berhak pula memperoleh perlindungan dalam pelaksanaan tugas dan hak kekayaan intelektual sebagaimana di atur Pasal 14 ayat (1) huruf $\mathrm{c}$ undang-undang ini.

Meskipun guru secara normatif diberikan perlindungan, namun hingga saat ini belum ada peraturan pelaksana yang secara teknis operasional mengatur berbagai macam perlindungan terhadap guru, termasuk perlindungan hukumnya. Perlindungan hukum sebagaimana Pasal 39 ayat (3) Undang-Undang Nomor 14 Tahun 2005 Tentang Guru hanya menentukan: "Perlindungan hukum sebagaimana dimaksud pada ayat (2) mencakup perlindungan hukum terhadap tindak kekerasan, ancaman, perlakuan diskriminatif, intimidasi, atau perlakuan tidak adil dari pihak peserta didik, orang tua peserta didik, masyarakat, birokrasi, atau pihak lain." Akibatnya, tidak jarang guru diadukan secara hukum dan bahkan dikriminalisasi oleh berbagai pihak antara lain: peserta didik (siswa), orang tua atau wali siswa, dan masyarakat mengatasnamakan pendidikan ${ }^{20}$

Orangtua siswa pada beberapa kasus menggunakan undang-undang perlindungan anak sebagai tuduhan pelanggaran hukum yang dilakukan oleh guru. Pasal yang sering pula digunakan dalam memenjarakan guru adalah Pasal 54 yang berbunyi "setiap anak berhak mendapatkan perlindungan di satuan pendidikan dari kejahatan seksual dan kekerasan yang dilakukan oleh pendidik, tenaga kependidikan, sesama peserta didik, dan/atau pihak lain". Pasal tersebut akhirnya membatasi ruang gerak guru dalam melaksanakan proses pendidikan di sekolah.

Perilaku siswa lebih dominan dibentuk oleh pola didik keluarga serta lingkungan masyarakatnya karena mereka lebih banyak menghabiskan waktunya pada kedua lingkungan tersebut. Sebagai contoh perilaku berbahasan anak yang sangat dipengaruhi oleh lingkungan keluarga dan

${ }^{19}$ Ibid

${ }^{20}$ Harisman, Perlindungan Hukum Bagi Guru Dalam Menjalankan Tugas Pendidikan Dan Pengajaran, De Lega Lata Jurnal Ilmu Hukum Fakultas Hukum Umsu, Volume 5 Nomor 1, Januari - Juni 2020, hlm 88, http://jurnal.umsu.ac.id/index.php/ delegalata/ article/view/ 3452/3488,diakses pada tanggal 02/09/2021. Pukul 23.19 WIB 
PRESUMPTION of LAW

Fakultas Hukum Universitas Majalengka

Volume 3 Nomor 2 Oktober 2021

masyarakat dibandingkan dengan lingkungan sekolah. Kurangnya penanaman akhlak oleh orangtua kepada anaknya sangat berpengaruh pada prilaku anak di sekolah. Orangtua harus menyadari bahwa tindakan yang dilakukan guru di sekolah hanya ingin membantu peran orangtua sebagai pendidik utama bagi anak-anaknya. Namun saat ini, orangtua tidak segan lagi untuk melaporkan serta memenjarakan guru yang mereka anggap melakukan tindakan yang salah dalam mendidik anak-anaknya di sekolah. Efek yang dapat ditimbulkan oleh permasalahan tersebut adalah perubahan pola fikir atau cara pandang guru dalam mendidik siswa di sekolah, sehingga dalam setiap tindakan pendisiplinan siswa, guru selalu dibayangbayangi oleh undang-undang perlindungan anak. Ketakutan yang dialami guru tersebut, akan berdampak besar terhadap keberlangsungan pendidikan Indonesia. Undang-undang perlindungan anak membuat guru lebih memilih bersikap aman daripada harus mengambil resiko yang dapat menyeretnya pada proses hukum. Hal ini tentu berdampak besar terhadap kemajuan pendidikan nasional jika guru menjadi pasif karena mereka tidak terlindungi secara hukum dalam mendidik siswa.

Sikap guru dalam mendidik mengalami perubahan semenjak banyaknya penganiayaan dan kasus hukum yang dialami guru. Secara ideal, guru akan berusaha semaksimal mungkin dalam mendidik siswanya dan tidak segan untuk melakukan tindakan tegas demi kebaikan dan keberhasilan siswa. Namun, undang-undang perlindungan anak membuat guru harus mengubah pola didiknya. Saat ini guru hanya boleh mendidik dengan penuh kelembutan tanpa adanya tindakan tegas apalagi menyentuh siswa secara fisik. Permasalahannya adalah karakteristik siswa yang berbeda-beda sehingga terdapat siswa yang dapat didisiplinkan hanya dengan cara kelembutan tetapi terdapat pula siswa yang tidak dapat didisiplinkan jika tidak dengan ketegasan. ${ }^{21}$

Sikap guru dalam mendidik berpengaruh signifikan terhadap perkembangan dan kemajuan bangsa. Salah satu indikator keberhasilan pendidikan adalah ketika sikap dan perilaku siswa mencerminkan akhlak yang baik. Hanya saja lemahnya perlindungan hukum bagi guru membuat guru tidak dapat mendidik siswa secara maksimal. Oleh sebab itu, pasalpasal yang membatasi ruang gerak guru dalam melaksanakan proses pendidikan di sekolah harus di rekronstruksi kembali.

\section{F. Kesimpulan}

1. Undang-undang perlindungan anak memberikan dampak terhadap guru dalam mendidik. Guru berada pada posisi yang dilematis, antara tugas mulia menyalurkan ilmu pengetahuan dan perlakukan orang tua murid. Mereka dituntut untuk mampu menjadikan peserta didik mencapai tujuan pendidikan. Namun saat guru berupaya untuk menegakkan kedisplinan, guru dihadang oleh Undang-Undang Perlindungan Anak. Sehingga muncullah sikap apatis dan ketidakpedulian dari seorang guru terhadap

${ }^{21}$ Ahmad Munawir, paradigma guru dan orangtua...Op.Cit hlm 119 
tingkah laku murid karena mereka takut berhadapan dengan hukum walaupun undang-undang telah memberikan perlindungan kepadanya. Oleh sebab itu, pasal-pasal perlindungan anak yang membatasi ruang gerak guru dalam melaksanakan proses pendidikan di sekolah harus di rekronstruksi kembali.

2. Sikap guru dalam mendidik mengalami perubahan semenjak banyaknya kasus hukum yang dialami guru. Secara ideal, guru akan berusaha semaksimal mungkin dalam mendidik siswanya dan tidak segan untuk melakukan tindakan tegas demi kebaikan dan keberhasilan siswa. Namun, undang-undang perlindungan anak membuat guru harus mengubah pola didiknya. Saat ini guru hanya boleh mendidik dengan penuh kelembutan tanpa adanya tindakan tegas apalagi menyentuh siswa secara fisik. Permasalahannya adalah karakteristik siswa yang berbeda-beda sehingga terdapat siswa yang dapat didisiplinkan hanya dengan cara kelembutan tetapi terdapat pula siswa yang tidak dapat didisiplinkan jika tidak dengan ketegasan

Undang-undang perlindungan anak membuat guru lebih memilih bersikap aman daripada harus mengambil resiko yang dapat menyeretnya pada proses hukum. Hal ini tentu berdampak besar terhadap kemajuan pendidikan nasional jika guru menjadi pasif karena mereka tidak terlindungi secara hukum dalam mendidik siswa.

\section{G. Saran}

1. Kepada lembaga legislatif dan pemerintah diharapkan dapat mengkaji ulang Undang-Undang Perlindungan Anak yang berkaitan dengan ruang gerak guru dalam melaksanakan proses pendidikan di sekolah

2. Kepada Dinas Pendidikan baik Kabupaten maupun Kota, disarankan untuk melakukan sosialisasi tentang hak dan kewajiban guru dalam mendidik dan mendisiplinkan siswa secara lebih masif lagi sehingga bukan hanya guru yang memahami akan hak dan kewajibannnya, akan tetapi siswa dan orangtua juga sama-sama memahaminya. 


\section{DAFTAR PUSTAKA}

\section{A. Buku}

E Mulyasa, Menjadi Guru Profesional, Remaja Rosdakarya, Bandung, 2006.

Johnny Ibrahim, Teori dan Metodologi Penelitian Hukum Normatif, Bayumedia Publishing, Cet. IV, Malang, 2008.

Jonaedi Efendi, Johnny Ibrahim, Metode Penelitian Hukum Normatif dan Empiris, Prenadamedia Group, Depok, 2018.

Marlina, Peradilan Pidana Anak di Indonesia, Refika Aditama Bandung, 2012

\section{B. Peraturan Perundang-undangan}

Undang-Undang Dasar Negara Republik Indonesia Tahun 1945.

Undang-Undang Nomor 14 tahun 2005 tentang guru dan dosen

Undang-Undang Nomor 35 Tahun 2014 tentang Perubahan atas Undangundang Nomor 23 Tahun 2002 tentang Perlindungan Anak

Undang-undang Nomor 39 Tahun 1999 tentang Hak Asasi Manusia

Paraturan Pemerintah Nomor 74 Tahun 2008 tentang Guru

\section{Sumber Lain}

Agus Affandi, Dampak Pemberlakuan Undang-Undang Perlindungan Anak Terhadap Guru Dalam Mendidik Siswa, Jurnal Hukum Samudra Keadilan Volume 11, Nomor 2, Juli-Desember 2016, https://jurnal.unsam.ac.id/ index.php/jhsk/article/view/37/18 diakses pada tanggal 10 Juli 2021 Pukul 23.15 WIB

Ateng Sudibyo dan Eki Kiyamudin, perlindungan hukum terhadap guru dalam melaksanakan tugas keprofesionalannya dikaitkan dengan punishment dalam mendisiplinkan siswa, Presumption Of Law, Fakultas Hukum Universitas Majalengka, Volume 1 Nomor 2 Tahun 2019, https://ejournal.unma.ac.id/index.php/jpl/article/view/89, hlm 54, diakses pada tanggal 03/09/2021. Pukul 08.52 WIB

Ahmad Munawir, paradigma guru dan orangtua terhadap penerapan Undang-Undang Perlindungan Anak Di Sekolah, Al-Amwal: Journal of Islamic Economic Law September 2019, Vol. 4, No. 2, https:// ejournal. iainpalopo.ac.id/index.php/alamwal/index diakses pada tanggal $10 \mathrm{Juli}$ 2021 Pukul 23.15 WIB 
PRESUMPTION of LAW

Fakultas Hukum Universitas Majalengka

Volume 3 Nomor 2 Oktober 2021

Brilio, Benarkah guru pukul murid itu melanggar undang-undang? Ini jawabannya, https://www.brilio.net/serius/benarkah-guru-pukul-muriditu-melanggar-undang-undang-ini-jawabannya-160812f.html diakses pada tanggal 10 Juli 2021 Pukul 23.15 WIB

Harisman, Perlindungan Hukum Bagi Guru Dalam Menjalankan Tugas Pendidikan Dan Pengajaran, De Lega Lata Jurnal Ilmu Hukum Fakultas Hukum Umsu, Volume 5 Nomor 1, Januari - Juni 2020, http://jurnal. umsu.ac.id/index.php/ delegalata/ article/view/ 3452/3488, diakses pada tanggal 02/09/2021. Pukul 23.19 WIB

Jumriani Nawawi, Perlindungan Hukum Terhadap Profesi Guru Dari Kriminalisasi Di Indonesia, Jurnal Al-Adalah: Jurnal Hukum dan Politik Islam Vol. 4, No. 2, Juli 2019, https://media.neliti.com/media/ publications/326816-perlindungan-hukum-terhadap-guru-dari-kr65ae2e71.pdf diakses pada tanggal 10 Juli 2021 Pukul 23.15 WIB

Michael Pranoto, Implementasi Pasal 54 Undang-Undang No. 35 Tahun 2014 Tentang Perlindungan Anak Di Lingkungan Sekolah, Lex Crimen Vol. VI/No. 8/Okt/2017, https://ejournal.unsrat.ac.id/index.php/ lexcrimen/ article/ view/17933/17460, diakses pada tanggal 10 Juli 2021 Pukul 23.15 WIB

Yenny AS, Anita Yuliastini, Rini Setiawati, Membangun Kesadaran Hukum Tentang Perlindungan Anak Bagi Guru, Jces (Journal of Character Education Society), Vol. 3, No. 3, Oktober 2020. file:///C:/Users/ MINI\%20PC/Downloads/2580-10663-2-PB.pdf, diakses pada tanggal 10 Juli 2021 Pukul 23.15 WIB 